\title{
QUALITY OF LIFE IN PEOPLE WITH VENOUS ULCERS AND THE CHARACTERISTICS AND SYMPTOMS ASSOCIATED WITH THE WOUND
}

\author{
Uiara Aline de Oliveira Kaizer ${ }^{1, *} \mathbb{D}$, Elaine Aparecida Rocha Domingues² (D), \\ Ana Beatriz de Toledo Saib Paganelli2 (D)
}

\begin{abstract}
Objective: to evaluate the quality of life of people with venous ulcers and correlate with the clinical characteristics and symptoms associated with the wound. Method: quantitative, cross-sectional and analytical study. For analyzes of associations of qualitative variables, the Chi-square and Fisher's exact tests were applied, and for quantitative variables, Spearman's correlation coefficient. The Pressure Ulcer Scale for Healing instrument was used to assess the wound and the Freiburg Life Quality Assessment Wound-wk for quality of life analysis. The study included 103 subjects with a wound time of more than six weeks, of venous etiology. Results: there was a correlation between the clinical characteristics of the venous ulcer and symptoms associated with quality of life. In the physical symptoms dimensions, people with venous ulcers had a worse score in relation to the pain symptom $(p<0.0001)$. Associated with this, clinical characteristics such as the appearance $(p<0.0001)$ and the area $(p=$ 0.0037) of the wound also showed a correlation. Regarding the wound assessment scale (area, tissue in the wound and exudate), the worst score interfered with physical symptoms. Conclusion: the pain, size of the wound and its aspect negatively influences the quality of life of people with venous ulcers.
\end{abstract}

DESCRIPTORS: Varicose ulcer. Quality of life. Healing. Nursing. Stomatherapy.

\section{QUALIDADE DE VIDA EM PESSOAS COM ÚLCERA VENOSA E AS CARACTERÍSTICAS E SINTOMAS ASSOCIADOS À FERIDA}

\section{RESUMO}

Objetivo: avaliar a qualidade de vida de pessoas com úlcera venosa e correlacionar com as características clínicas e sintomas associados à ferida. Método: estudo quantitativo, transversal e analítico. Para as análises das associações das variáveis qualitativas foram aplicados os testes Qui-quadrado e exato de Fisher, e para as variáveis quantitativas, o coeficiente de correlação de Spearman. Utilizou-se o instrumento Pressure Ulcer Scale for Healing para a avaliação da ferida e o Freiburg Life Quality Assessment Wound-wk para análise da qualidade de vida. Fizeram parte do estudo 103 sujeitos com tempo de feridas superior a seis semanas, de etiologia venosa. Resultados: houve correlação das características clínicas da úlcera venosa e sintomas associados com a qualidade de vida. Nas dimensões sintomas físicos, pessoas com úlcera venosa apresentraram pior escore em relação ao sintoma dor $(p<0,0001)$. Associadas a isso, as características clínicas como a aparência $(p<0,0001)$ e a área

1. Universidade Estadual de Campinas - Faculdade de Enfermagem - Departamento de Enfermagem - Sorocaba (SP), Brazil. 2. Universidade Vale do Rio Verde - Faculdade de Enfermagem - Departamento de Enfermagem - Três Corações (MG), Brazil. *Correspondence author: uiara_oliveira@hotmail.com

Section Editor: Juliano Teixeira Moraes

Received: Nov. 04, 2020 | Accepted: Dez. 14, 2020

How to cite: Kaizer UOA; Domingues EAR; Paganelli ABTS. Quality of life in people with venous ulcers and the characteristics and symptoms associated with the wound. ESTIMA, Braz. J. Enterostomal Ther., 2020, 19: e0121. https://doi.org/10.30886/estima.v19.968_IN 
$(p=0,0037)$ da ferida também manifestaram correlação. Em relação à escala de avaliação da ferida (área, tecido na ferida e exsudato), o pior escore interferiu nos sintomas físicos. Conclusão: a dor, tamanho da ferida e seu aspecto influenciam negativamente na qualidade de vida de pessoas com úlcera venosa.

DESCRITORES: Úlcera varicosa. Qualidade de vida. Cicatrização. Enfermagem. Estomaterapia.

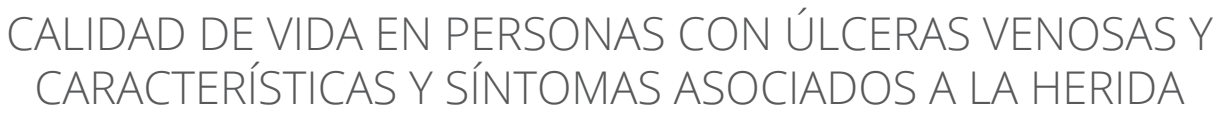

\section{RESUMEN}

Objetivo: evaluar la calidad de vida de las personas con úlceras venosas y correlacionarlas con las características clínicas y síntomas asociados a la herida. Método: estudio cuantitativo, transversal y analítico. Para los análisis de asociaciones de variables cualitativas se aplicaron las pruebas de Chi-cuadrado y exacta de Fisher y para las cuantitativas, el coeficiente de correlación de Spearman. Se utilizó el instrumento Escala de cicatrización de úlceras por presión (PUSH) para la evaluación de heridas y la Evaluación de la calidad de vida de Freiburg Wound -wk para el análisis de la calidad de vida. El estudio incluyó a 103 sujetos con un tiempo de herida mayor de seis semanas, de etiología venosa. Resultados: hubo correlación entre las características clínicas de la úlcera venosa y los síntomas asociados a la calidad de vida. En la dimensión de síntomas físicos, las personas con UV presentaron peor puntuación ante el síntoma de dolor ( $p<0,0001)$. En asociación, características clínicas como el aspecto $(p<0,0001)$ y el área ( $p=$ 0,0037) de la herida también mostraron una correlación. En cuanto a la escala de valoración de la herida (área, tejido de la herida y exudado), la peor puntuación interfirió con los síntomas físicos. Conclusión: el dolor, el tamaño de la herida y su aspecto influyen negativamente en la calidad de vida de las personas con úlceras venosas.

DESCRIPTORES: Úlcera venosa. Calidad de vida. Curación. Enfermería. Estomaterapia.

\section{INTRODUCTION}

Chronic wounds represent a serious public health problem, as they have high rates of incidence and prevalence in a worldwide scenario. This context doubles in rates when referring to individuals aged 65 and over, primarily female over $70^{1}$.

The prevalent leg ulcers are venous ulcers (VU) and with high rates of recurrence, caused by venous hypertension and characterized by the slowed tissue repair process. They primarily affect the perimaleolar region, and present as clinical features edema, eczema, varicose veins, irregular borders and exudate in large quantities ${ }^{2}$.

The pathophysiological process of VU is related to a combination of microscopic and macroscopic mechanisms. Macroscopic changes concern the development of varicose veins, changes in vein structures and cellular anomalies that damage the function of the venous system. This situation is due to genetic factors and venous hypertension ${ }^{3}$.Venous hypertension causes a chronic inflammatory response due to the extravasation of macromolecules, such as red blood cells, fibrinogen and iron, which succeed in degradation, exacerbating the local inflammatory response. With the chronic inflammatory process, chemotaxis attracts leukocytes to the site and releases abundant pro-inflammatory cytokines that elevate skin tissue damage ${ }^{3}$.

The impact that UV causes is notable in people of any age group, mainly due to its chronicity and high recurrence rates. Its presence reflects negatively on quality of life (QoL) due to the biopsychospiritual and economic impact for individuals and their families ${ }^{4}$.

The definitions that permeate QoL are many, in different areas and are related to their ability to define and measure large dimensions, being directed to the field of health, receiving the denomination of Quality of Life Related to Health 
(HRQoL), incorporating several aspects, such as health status, physical symptoms, disabilities, emotional factors and well-being 5 .

In the physical and psychosocial aspects, people with VU are affected by pain and difficulties in walking, becoming limited to domestic and work activities. In addition, the emotional and social state is compromised, as some individuals feel ashamed of the situation. Thus, they need care focused on problems, in order to reestablish QoL and return to their daily activities ${ }^{4,6,7}$.

Studies show that VU interferes with QoL, mainly in the physical aspects alluding to the clinical characteristics of VU (wound area, exudate and appearance of the wound) and the associated symptoms, such as the main complaint, pain ${ }^{8,9}$.Thus, it is necessary for professionals to provide comprehensive care to patients with $\mathrm{VU}$, identifying the peculiarities of VU and the associated symptoms that have a negative impact on QoL to guide their care.

Based on the context, the following guiding question emerged: do the clinical characteristics of the wound and the associated symptoms influence the QoL of people with VU? Therefore, the aim of the study is to assess the QoL of people with VU and correlate with the clinical characteristics and symptoms associated with the wound.

\section{METHOD}

This is a cross-sectional observational study of a series of cases, with secondary data from a primary research related to the evaluation of QoL in people with VU submitted to an intervention ${ }^{10}$. The study was carried out in three specialized care units for people with injuries, from November 2016 to July 2017.

The service units are located in the south of Minas Gerais and São Paulo. The protocol in the care of people with VU consists of the assessment of VU by nurses and vascular doctors. Patients undergo imaging tests and AnkleBrachial Index (ABI) for the diagnosis of VU, and then a prescription is made according to the characteristics of the wound, associated with compression therapy.

The study participants were recruited from the referred units, using a list requested by the researcher from the nurse responsible for the unit, containing the patient's name, medical record number and phone number. Recruitment was carried out according to the patient's scheduling at the unit of origin for routine monitoring. Patients were selected according to their arrival at the unit for treatment, before dressing, in the waiting room.

People with VU participated in the study, according to the following criteria: patients of both sexes and with ABI between 0.8 and $1.3 \mathrm{mmHg}$, with VU time greater than 6 weeks. Patients diagnosed with diabetes mellitus and infected ulcers were excluded from the study.

For the sample calculation, the methodology of an Anova model of repeated measures was taken into account, assuming a significance level of 5\%, a test power of $80 \%$ and an effect size of 0.25 , which can be considered a medium grade effect size. The calculation resulted in a sample of 82 individuals. However, considering a rate of $20 \%$ for possible losses, the sample size totaled 98 subjects. The $\mathrm{G} *$ Power 3.1.9.2 software was used for the sample calculation.

The data were collected through interviews on printed paper and individually by the main researcher, in a private location. The socio-demographic and health data instrument was used to characterize the participants, developed by the researcher.

The Pressure Ulcer Scale for Healing (PUSH) instrument was used to assess wounds ${ }^{11}$. The PUSH is divided into three subscales: wound area (score ranges from 0 to 10); amount of exudate, classified as absent, small, moderate and large (score ranges from 0 to 3); and bed appearance (score ranges from 0 to 4 ). The total score is obtained by adding the subscales, ranging from 0 (healed wound) to 17 (worst condition).

For pain analysis, the numerical pain scale was used. It is a scale of 11 points, which is marked from 0 to 10 , where the end points are the extremes, being 0 (no pain) and 10 (worst pain imaginable) ${ }^{12}$.

To assess QoL, the FLQA-wk- short version instrument was used, adapted and validated in Brazil (2013) ${ }^{13}$. The instrument is specific to assess the HRQoL of people with chronic ulcers of different etiologies. The scale includes six 
domains: physical symptoms (pain, insomnia, itching and odor from the wound), daily life, social life, psychological well-being, wound treatment and satisfaction (health, wound and treatment). At the end of the instrument there is an assessment of the appearance of the wound in the patient's view, which he scores from zero (worst condition of the wound) to ten (good condition of the wound).

The total score is performed by the average of each response after recoding the satisfaction scale, that is, the values need to be inverted for the calculation. The total score is computed using the mean values of each domain. The QoL score varies from 1 to 1.25 (excellent QoL); 1.26 to 2.5 (mean QoL); 2.6 to 3.75 (regular QoL); and 3.76 to 5 (worst QoL).

To measure the lesion area, the UV photographic record was performed with an 8 megapixel digital camera, $f / 2.4$ aperture, Diode Light Emitting (LED) flash and computerized planimetry was used to calculate the area (Texas Health Science Center in San Antonio Image Tool, version 3.0, downloaded from www.ddsdx.uthsca.edu/dig/itdesc.html).

Data collection was performed after signing the Free and Informed Consent Form (ICF) and approval by the Ethics Committee under opinion no. 1,860,409. The ethical requirements of resolution 466/12 were respected.

The data were entered into Microsoft Office Excel 2010 and then evaluated using version 9.4 of the statistical software Statistical Analysis System (SAS). For the analysis, it was used for continuous variables, the mean and standard deviation, and for categorical variables, relative and absolute frequencies. In the associations between qualitative variables, the Chi-square and Fisher's exact tests were performed (in which the assumptions were not met). Spearman's correlation coefficient was applied for correlations between quantitative variables. A level of significance was considered when the $\mathrm{p}$-value is less than 0.0250 .

\section{RESULTS}

103 people with VU participated in the study, however, 33 were excluded as shown in Fig. 1. As shown in Table 1 , the average age was 66.5 years, with a male predominance (58.5\%), with $54,2 \%$ lived without partners, the income permeated 1.5 minimum wages and the individuals had an education of 3.8 years of study.

The result showed an average of 57.2 months of wound occurrence, ABI with an average of 1.0, use of elastic compression (88.5\%) and the prevalent treatment was the use of biguanide polyhexamethylene, calcium alginate and hydrogel. The average pain intensity was 5.2 points and the wound area was $11.9 \mathrm{~cm}^{2}$.

Regarding the PUSH scale, the total score was 10.9; the wound area had a score of 6.6; the amount of exudate and the predominant tissue in the ulcer bed had scores of 1.9 and 2.3 , respectively.



DM = Diabetes Mellitus; $\mathrm{ABI}=$ Ankle-Brachial Index.

Figure 1. Flowchart of the participants - Três Corações (MG), Brasil - 2019. 
Table 1. Personal and clinical data of people with venous ulcers ( $n=70)$. Três Corações (MG), Brasil - 2019.

\begin{tabular}{|c|c|c|c|c|c|}
\hline Variable & $\begin{array}{l}\text { Absolute } \\
\text { frequency }\end{array}$ & $\begin{array}{l}\text { Relative } \\
\text { frequency }\end{array}$ & $\begin{array}{l}\text { Medium } \\
\text { (SD) }\end{array}$ & $\begin{array}{l}\text { Minimum } \\
\text { value }\end{array}$ & $\begin{array}{l}\text { Maximum } \\
\text { value }\end{array}$ \\
\hline Age (years) & & & $66.5(12.8)$ & 38 & 93 \\
\hline \multicolumn{6}{|l|}{ Gender } \\
\hline Female & 29 & $41.4 \%$ & & & \\
\hline Male & 41 & $58.5 \%$ & & & \\
\hline \multicolumn{6}{|l|}{ Marital status } \\
\hline With companion & 32 & $45.7 \%$ & & & \\
\hline Without companion & 38 & $54.2 \%$ & & & \\
\hline \multicolumn{6}{|l|}{ Treatment } \\
\hline Petrolatum, hydrocolloid plate and papain & 12 & $17.1 \%$ & & & \\
\hline Calcium alginate, hydrogel and phmb & 56 & $80.0 \%$ & & & \\
\hline Others & 2 & $2.8 \%$ & & & \\
\hline \multicolumn{6}{|l|}{ Compression } \\
\hline Elastic & 62 & $88.5 \%$ & & & \\
\hline Inelastic & 8 & $11.4 \%$ & & & \\
\hline Wage income & & & $1.5(0.01)$ & 1 & 5 \\
\hline Schooling (years) & & & $3.8(0.1)$ & 0 & 13 \\
\hline $\mathrm{ABI}(\mathrm{mmHg})$ & & & $1.0(0.007)$ & 0.9 & 1.2 \\
\hline Wound time (months) & & & $57.2(1.8)$ & 2 & 300 \\
\hline Pain (0-10) & & & $5.2(3.7)$ & 0 & 10 \\
\hline Wound area $\left(\mathrm{cm}^{2}\right)$ & & & $11.9(16.7)$ & 0.17 & 92.41 \\
\hline Area - PUSH & & & $6.6(2.6)$ & 1 & 10 \\
\hline Exudate - PUSH & & & $1.9(0.6)$ & 1 & 3 \\
\hline Tissue - PUSH & & & $2.3(0.5)$ & 2 & 4 \\
\hline Total score PUSH & & & $10.9(3.1)$ & 5 & 16 \\
\hline
\end{tabular}

SD = standard deviation; PHMB = Polyhexamethylene biguanide; ABI = Ankle-Brachial Index; PUSH = Pressure Ulcer Scale for Healing.

Table 2 highlights the QoL score and its domains. The total score was 2.4 and the treatment (2.7) and daily life (2.7) domains were the ones that most negatively interfered with QoL, classified as regular QoL. On the wound state scale, the average score was 6.8 .

Table 3 shows the correlation between the clinical characteristics of VU and the symptoms associated with QoL. In the physical symptoms dimension, people with VU had a worse score in relation to the pain symptom ( $<<0.0001)$. Associated with this, the clinical characteristics, such as the appearance $(p<0.0001)$ and the area $(p=0.0037)$ of the wound also showed a correlation.

In the item satisfaction, pain improvement $(\mathrm{p}=0.0162)$ and wound aspects $(\mathrm{p}<0.0001)$ showed a significant correlation. So that the higher the score of the appearance of the wound, the lower the score of the satisfaction domain and vice versa. This inversely proportional relationship is determined by the negative Spearman correlation coefficient, showing that when one score increases or the other decreases. 
In the daily life dimension, the pain symptom $(\mathrm{p}=0.0024)$ demonstrated an impact on the individuals' daily lives. On the other hand, in the domains of social life, psychological well-being and treatment, there were no characteristics of the wound that directly interfered in these aspects.

Regarding the total QoL score, the symptom pain ( $\mathrm{p}<0.0001)$, appearance of the wound $(\mathrm{p}=0.0004)$ and PUSH score $(p=0.0220)$ interfere negatively in the QoL of people with VU.

Table 2. Quality of life score of patients with venous ulcers ( $n=70)$. Três Corações (UF), Brasil - 2019.

\begin{tabular}{lc}
\hline Domains & Medium (SD) \\
\hline Physical symptoms & $2.61(0.55)$ \\
\hline Daily life & $2.72(0.16)$ \\
\hline Social life & $2.17(0.48)$ \\
\hline Psychological well-being & $1.94(0.30)$ \\
\hline Treatment & $2.74(0.58)$ \\
\hline Satisfaction & $2.32(0.37)$ \\
\hline Total score & $2.45(0.75)$ \\
\hline Wound (0-10) & $6.8(2.5)$ \\
\hline
\end{tabular}

SD = standard deviation

Table 3. Correlation of the clinical characteristics of venous ulcers and symptoms associated with quality of life. Três Corações (MG), Brasil - 2019.

\begin{tabular}{|c|c|c|c|c|}
\hline Quality of life & $\begin{array}{l}\text { Pain } \\
(0-10)\end{array}$ & $\begin{array}{c}\text { Wound } \\
(0-10)\end{array}$ & $\begin{array}{l}\text { Wound area } \\
\qquad\left(\mathrm{cm}^{2}\right)\end{array}$ & $\begin{array}{l}\text { Score - Total } \\
\text { (PUSH) - (0-17) }\end{array}$ \\
\hline \multirow{2}{*}{ Score - physical symptoms } & 0.7685 & -0.5251 & 0.3428 & 0.3519 \\
\hline & $p<0.0001$ & $p<0.0001$ & $p=0.0037$ & $p=0.0030$ \\
\hline \multirow{2}{*}{ Score - daily life } & 0.3886 & -0.2741 & 0.2125 & 0.2321 \\
\hline & $p=0.0024$ & $p=0.0260$ & $p=0.0775$ & $p=0.0549$ \\
\hline \multirow{2}{*}{ Score - social life } & 0.2482 & -0.2002 & 0.0660 & 0.0857 \\
\hline & $p=0.0581$ & $p=0.1071$ & $p=0.5874$ & $p=0.4841$ \\
\hline \multirow{2}{*}{ Score - psychological well-being } & 0.2114 & -0.2248 & 0.0916 & 0.1213 \\
\hline & $p=0.1079$ & $p=0.0696$ & $p=0.4507$ & $p=0.3209$ \\
\hline \multirow{2}{*}{ Score - treatment } & 0.1384 & -0.2083 & 0.0504 & 0.0969 \\
\hline & $p=0.2960$ & $p=0.0933$ & $p=0.6787$ & $p=0.4284$ \\
\hline \multirow{2}{*}{ Score - satisfaction } & 0.3118 & -0.5773 & 0.2502 & 0.3221 \\
\hline & $p=0.0162$ & $p<0.0001$ & $p=0.0367$ & $p=0.0070$ \\
\hline \multirow{2}{*}{ Score - total (FLQA) } & 0.5057 & -0.4238 & 0.2442 & 0.2755 \\
\hline & $p<0.0001$ & $p=0.0004$ & $p=0.0416$ & $p=0.0220$ \\
\hline
\end{tabular}

Spearman's correlation coefficient and p-value $<0,025$

PUSH = Pressure Ulcer Scale for Healing; FLQA = Freiburg Life Quality Assessment.

Table 4 shows the relationship between the PUSH and QoL domains, showing that there was no significant correlation between them. 
Table 4. Correlation of the clinical characteristics of the lesion (Pressure Ulcer Scale for Healing) in quality of life. Três Corações (MG), Brasil - 2019.

\begin{tabular}{lc}
\hline Variable & QoL \\
\hline Total area & -0.0615 \\
\cline { 2 - 2 } Exudate & $\mathrm{p}=0.6268$ \\
\hline Wound bed tissue & 0.0685 \\
\hline
\end{tabular}

Spearman's correlation coefficient and p-value $<0.025$

QoL = Quality of life

\section{DISCUSSION}

The study showed a higher frequency of VU in elderly men with low income and education level. This scenario corroborates international and national studies on the profile of this population, and emphasizes that people with VU need specialized attention with regard to comprehensive care, promoting tissue repair and reducing recurrences and, consequently, improving QoL $8,9,13-15$.

In this research, people with VU had low QoL, influenced by the impact that the wound has on daily life, their physical symptoms, especially pain and by the peculiar clinical signs present (size and appearance of the wound) ${ }^{13}$. Studies that relate pain and QoL highlight that specialized pain care is a predictive care for improving QoL, in terms of its assessment, the use of validated scales and the identification of factors that alleviate or worsen the symptom. They are fundamental nursing care for symptom control ${ }^{16-18}$.

Another study ${ }^{19}$,that also analyzed pain in cases of VU, found that due to the complaint of severe pain by people with VU, in addition to the use of medication to control this symptom, other non-pharmacological methods are necessary, including a good family, social and leisure. Otherwise, people can isolate themselves from society, develop low self-esteem and even depression, further compromising their QoL.

Linked to the physical symptom, individuals with VU have difficulty performing their daily tasks, as the wounds specifically affect the lower limbs and soon cause important physical limitations. Linked to this, extensive and bad-looking wounds further impair patients' daily lives, in addition to shame and social isolation ${ }^{7}$.

The research corroborates to highlight that the depth, size and the presence of exudate in the VU cause disability and limitations. Patients lose their QoL, as they avoid social contact, stop performing their activities, become isolated, and this situation leads to depressive conditions. In addition, the fact that there is an exudate that can present a foul odor due to infections, or even the appearance of the lesion can result in repulsions, such as not eating properly, which generates impairment in the healing process and a low $\mathrm{QoL}^{20}$.

In addition to pain, the appearance of the wound and its extent were clinical aspects that negatively impacted the QoL of participants with VU. Therefore, it is worth highlighting the importance of the nursing professional in this context, since it has the theoretical foundation and the ability to provide assistance to patients with altered skin integrity. To assist in reducing the time for tissue repair, the professional must use assessment tools to monitor the evolution as well as to know the different technologies and innovations available in the market for the treatment of wounds in general, and to analyze the systemic and local factors that interfere in the healing ${ }^{21}$.

The main contribution of this study to VU research was to identify the clinical factors that most affect the QoL of people with chronic VU and which domains are most affected, for better planning of care provided and also to develop programs aimed at comprehensive care of these cases, with information to support the health, prevention and treatment 
policies of these people, aiming to improve their QoL. It is worth mentioning that the questionnaire used for the research is a specific instrument that assesses the QoL of people with $\mathrm{VU}$ and addresses the dimension of wound treatment, one of the items that most negatively influenced the QoL of the participants, which differs from other instruments in the literature. In addition, the domains physical symptoms and daily activity had an impact on the life of patients with VU. All these changes interfere in the daily life of the patient with a wound, and an effective care planning promotes tissue repair and improves perception, favoring the well-being and QoL of the person with VU9

As a limitation of this study, it is highlighted that the data are secondary to a primary research related to lifestyle in patients with VU, however, the objective was related to QoL. Furthermore, the bias of collecting QoL data through interviews and not by self-completion stands out, as participants may omit information because they feel embarrassed to answer questions.

\section{CONCLUSION}

People with VU have decreased QoL, as the presence and clinical characteristics of the wound (extension of the wound, amount of exudate and presence of tissue in the bed) and the pain symptom impair the daily life of the patient and their family. The treatment offered to people with VU and their physical symptoms were the dimensions that most characterized QoL, so health professionals need to explain clearly and objectively the importance of treatment and self-care guidelines so that the person understands and follows the recommendations to achieve tissue repair. When correlating the symptoms and the clinical characteristics of VU, it became evident that the physical symptoms, mainly, the intensity of pain, area and appearance of the wound are unfavorable aspects that negatively interfere in QoL.

\section{AUTHORS `CONTRIBUTION}

Conceptualization: Domingues EAR; Methodology: Domingues EAR; Research: Domingues EAR and Kaizer UAO; Writing - First version: Paganelli ABTS, Kaizer UAO and Domingues EAR; Writing - Review \& Editing: Paganelli ABTS, Kaizer UAO and Domingues EAR; Supervision: Kaizer UAO and Domingues EAR.

\section{DATA AVAILABILITY STATEMENT}

Data will be available upon request.

\section{FUNDING}

Not applicable.

\section{ACKNOWLEDGMENTS}

Not applicable.

\section{REFERENCES}

1. Pérez MB, López-Casanova P, Lavín RS, Torre HG, Verdú-Soriano J. Epidemiology of venous leg ulcers in primary health care: Incidence and prevalence in a health centre-A time series study (2010-2014). Int Wound J 2019;16(1):256-65. https://doi. org/10.1111/iwj.13026

2. Sánchez-Nicolat NE y cols. Úlceras venosas. Rev Mex Angiol 2019;47(1):26-38. 
3. Crawford JM, Lal BK, Durán WN, Pappas PJ. Pathophysiology of venous ulceration. J Vasc Surg Venous Lymphat Disord 2017 jul;5(4):596-605. https://doi.org/10.1016/j.jvsv.2017.03.015

4. Araújo RO, Silva DC, Souto RQ, Pergola-Marconato AM, Costa IKF, Torres GV. Impacto de úlceras venosas na qualidade de vida de indivíduos atendidos na atenção primária. Aquichan 2016:16(1):56-66. https://doi.org/10.5294/aqui.2016.16.1.7

5. Karimi M, Brazier J. Health, Health-Related Quality of Life, and Quality of Life: What is the Difference? Pharmacoeconomics 2016;34(7):645-9. https://doi.org/10.1007/s40273-016-0389-9

6. Barbosa MLG, Salomé GM, Ferreira LM. Avaliação da ansiedade e da depressão em paciente com úlcera venosa tratados com acupuntura. Rev Enferm UFP on line 2017; [Cited 2018 sep 6]; 11(Supl.9):3574-82. Available at: https://periodicos.ufpe.br/ revistas/revistaenfermagem/article/download/234488/27686

7. Joaquim FL, Silva RMCRA, Garcia-Caro MP, Cruz-Quintana F, Pereira ER. Impact of venous ulcers on patients' quality of life: an integrative review. Rev Bras Enferm 2018 Jul-Aug;71(4):2021-9. https://doi.org/10.1590/0034-7167-2017-0516

8. Santos KFR, Silva PR, Ferreira VT, Domingues EAR, Simões IRA, Lima RS et al. Quality of life of people with chronic ulcers. J Vasc Nurs 2016 Dec;34(4):131-6. https://doi.org/10.1016/j.jvn.2016.06.003

9. Torres SMSSO, Araújo RO, Costa IKF, Tibúrcio MP, Sousa AJG, Pergola-Marconato AM et al. Health-related quality of life in patients with venous leg ulcer treated in primary care in Brazil and Portugal. PLoS One 2018;13(4):e0195990. https://doi. org/10.1371/journal.pone.0195990

10. Domingues EAR, Kaizer UAO, Lima MHM. Effectiveness of the strategies of an orientation programme for the lifestyle and wound-healing process in patients with venous ulcer: A randomised controlled trial. Int Wound J 2018;15(5):798-806. https:// doi.org/10.1111/iwj.12930

11. Santos VLCG, Carvalho VF. Reapresentando o instrumento Pressure Ulcer Scale for Healing (PUSH) para avaliação de úlceras por pressão e úlceras crônicas de perna. ESTIMA, Braz J Enterestomal Ther 2009;7(2):19-27. Available at: https://www. revistaestima.com.br/estima/article/view/256

12. Karcioglu O, Topacoglu H, Dikme O, Dikme O. A systematic review of the pain scales in adults: Which to use? Am J Emerg Med 2018 Apr;36(4):707-14. https://doi.org/10.1016/j.ajem.2018.01.008

13. Domingues EAR, Alexandre NMC, Silva JV. Adaptação cultural e validação do Freiburg Life Quality Assessment-Wound para a língua portuguesa do Brasil. Rev Latino-Am Enfermagem 2016;24:e2684. http://doi.org/10.1590/1518-8345.0289.2684

14. Torre HG, Quintana-Lorenzo ML, Perdomo-Pérez E, Verdú J. Correlation between health-related quality of life and venous leg ulcer's severity and characteristics: a cross-sectional study. Int Wound J 2017;14(2):360-8. https://doi.org/10.1111/iwj.12610

15. Souza EM, Yoshida WB, Melo VA, Aragão JA, Oliveira LAB. Ulcer due to chronic venous disease: a sociodemographic study in northeastern Brazil. Ann Vasc Surg. 2013 Jul;27(5):571-6. https://doi.org/10.1016/j.avsg.2012.07.021

16. Silva DC, Budó MLD, Schimith MD, Salvetti MG, Torres GV. Estratégias pessoais de alívio da dor utilizadas por pacientes com úlcera venosa. Rev Dor 2015;16(2):86-9. https://doi.org/10.5935/1806-0013.20150017

17. Santos VLCG, Oliveira AS, Amaral AFS, Nishi ET, Junqueira JB, Kim SHP. Quality of life in patients with chronic wounds: magnitude of changes and predictive factors. Rev esc enferm USP 2017;51:e03250. https://doi.org/10.1590/s1980-220x2016049603250

18. Lentsck MH, Baratieri T, Trincaus MR, Mattei AP, Miyahara CTS. Quality of life related to clinical aspects in people with chronic wound. Rev Esc Enferm USP 2018;52:e03384. https://doi.org/10.1590/S1980-220X2017004003384

19. Brito D, Xavier V, Santos J, Agra G. Dor em úlcera crônica: perfil sociodemográfico, clínico e terapêutico de pacientes de Cuité-PB. J Aging Innovation 2017; [Cited 2018 Sep 6]; 6(2):17-31 Available at: http://www.journalofagingandinnovation.org/ wp-content/uploads/3-artigo-dor-em-\%C3\%9Alcera-cr\%C3\%94nica-24_04_17.pdf

20. Almeida WA, Ferreira AM, Ivo ML, Rigotti MA, Barcelos LS, Silva ALNV. Fatores associados à qualidade de vida de pessoas com feridas complexas crônicas. Rev Fund Care Online 2018;10(1):9-16. https://doi.org/10.9789/2175-5361.2018.v10i1.9-16

21. Lumbers M. TIMERS: undertaking wound assessment in the community. Br J Community Nurs 2019;24(Sup12):S22-5. https:// doi.org/10.12968/bjen.2019.24.Sup12.S22 